\title{
Evaluation of the Effect of Nigella Sativa Hydro-alcoholic Extract and Honey on Gonadotropins and Sex Hormones Level in the Polycystic Ovarian Syndrome Model of Wistar Rat
}

\author{
Seiyedehnarjes Naseran ${ }^{1}$, Mokhtar Mokhtari $^{2}$, Mahmood Abedinzade ${ }^{3}$, Mehrdad Shariati $^{4}$ \\ 1. PhD of Animal physiology, Department of Biology, Kazerun Branch, Islamic Azad University, Kazerun, Iran. ORCID ID: \\ 0000-0001-9029-5735 \\ 2. Professor in Animal physiology, Department of Biology, Kazerun Branch, Islamic Azad University, Kazerun, Iran., \\ (Corresponding Author), Tel: 07142239933 Email: M.Mokhtari246@yahoo.com, ORCID ID: 0000-0002-9788-3449 \\ 3. Associate professor of physiology, Department of Physiology, Medical Biotechnology Research Center, School of \\ Paramedicine, Guilan University of Medical Sciences, Rasht, Iran. ORCID ID: 0000-0002-9216-7216. \\ 4. Associate Professor of Animal physiology, Department of Biology, Kazerun Branch, Islamic Azad University, Kazerun, \\ Iran. ORCID ID: 0000-0001-7360-0208
}

\begin{abstract}
Background and Aim :Polycystic ovary syndrome (PCOS) is one of the most common endocrine disorders of women in reproductive age. Anovulation and hyperandrogenism due to PCOS are major causes of infertility. The aim of the present study was to evaluate the combined effect of Nigella Sativa hydro-alcoholic extract and honey on gonadotropins and sex hormones level inpolycystic ovary syndrome in rats.

Materials and Methods: 40 adult Wistar rats, weighting $200-220 \mathrm{~g}$ were divided randomly into 5 groups: including intact, Sham (letrozole solvent), PCOS and 2 experimental PCOS groups. Rats were treated with letrozole for 21 days to induce PCOS. In the experimental groups, PCOS rats were treated with 2 doses of combination $300 \mathrm{mg} / \mathrm{kg}$ Nigella sativa extract with $1200 \mathrm{mg} / \mathrm{kg}$ honey and $600 \mathrm{mg} / \mathrm{kg}$ Nigella sativa extract with $2400 \mathrm{mg} / \mathrm{kg}$ honey for 28 days. The serum levels of LH, FSH, estrogen, progesterone and testosterone were measured by ELISA method and each serum were analyzed using ANOVA and TUKEY statistical tests $(\mathrm{P}<0.05)$.
\end{abstract}

Results: A significant decrease was seen in serum levels of $\mathrm{LH}$, estrogen and testosterone $(\mathrm{P}<0.05)$ in PCOS group treated with maximum dose of combination of $\mathrm{N}$. sativa extract and Honey compared with the PCOS group. Whereas, a significant increase in serum levels FSH in PCOS group treated with maximum dose and progesterone in the PCOS group treated with maximum and minimum dose of combination of N. sativa extract and Honey compared with the PCOS group $(\mathrm{p}<0.05)$.

Conclusion: Beneficial effects of combination of N. sativa extract and Honey was seen but further study is needed.

Keywords: Nigella Sativa, Honey, Polycystic Ovarian Syndrome, Rat

Received: June 19, $2019 \quad$ Accepted: Oct 26, 2019

How to cite the article: Seiyedehnarjes Naseran, Mokhtar Mokhtari, Mahmood Abedinzade,

Mehrdad Shariati. Evaluation of the Effect of Nigella Sativa Hydro-alcoholic Extract and Honey on

Gonadotropins and Sex Hormones Level in the Polycystic Ovarian Syndrome Model of Wistar Rat.

SJKU 2020;25(1):117-129.

Copyright (C) 2018 the Author (s). Published by Kurdistan University of Medical Sciences. This is an open access article distributed under the terms of the Creative Commons Attribution-Non Commercial License 4.0 (CCBYNC), where it is permissible to download, share, remix, transform, and buildup the work provided it is properly cited. The work cannot be used commercially without permission from the journal 


\section{بررسى تأثير عصاره هيدروالكلى سياهدانه (Nigella Sativa) و عسل بر سطح كنادوترويّنها و هور مونهاى جنسى در مدل موش صحرايى مبتلا به سندروم تخمدان

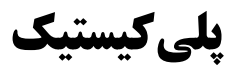 \\ سيده نرجس ناصران'، مختار مختارى ‘، محمود عابدين زاده"، مهرداد شريعتى}

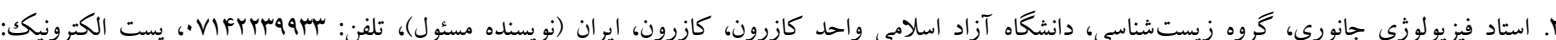

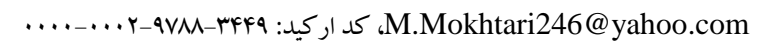

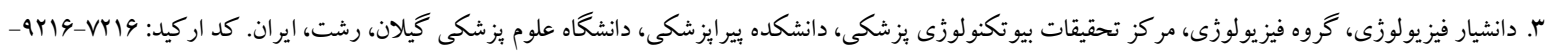
F. دانشيار فيزيولوزى جانورى، گروه زيست شناسى، دانشگاه آزاد اسلامى واحد كازرون، كازرون، ايران. كد اركيد:

زمينه و هدف: سندروم تخمدان بلى كيستيك(PCOS) يكى ازشايعترين اختلالات اندوكرين زنان در سن بارورى است. عدم تخمكك كذارى و هييراندروزنيسم ناشى از PCOS از عوامل عمدهى ايجاد نابارورى است. در اين مطالعه اثر تركيب عصاره

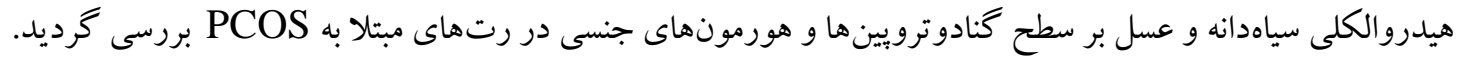

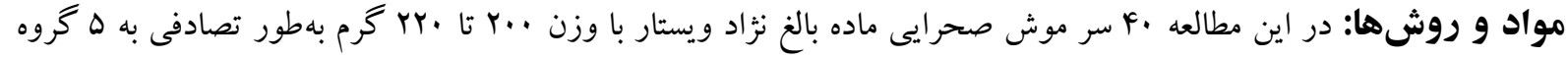

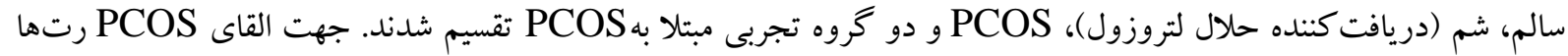
در طول مدت اب روز تحت تيمار لتروزول قرار گرفتند. در گروههاى تجربى رتهاى PCOS تحت تيمار با ب دوز از

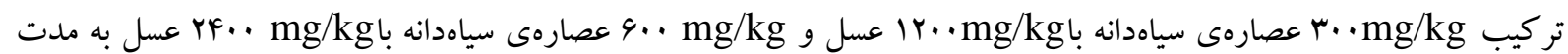

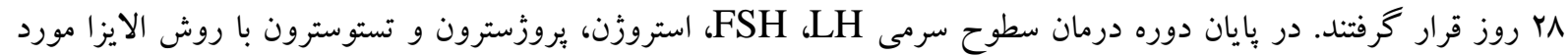
سنجش قرار گرفت و مقادير سرمى هر يكك با استفاده از آزمونهاى آمارى ANOVAو و

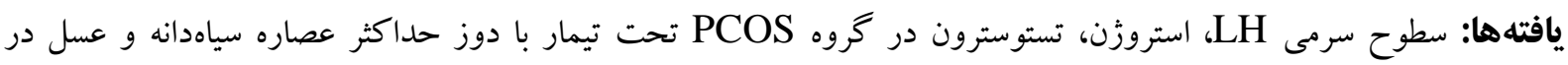

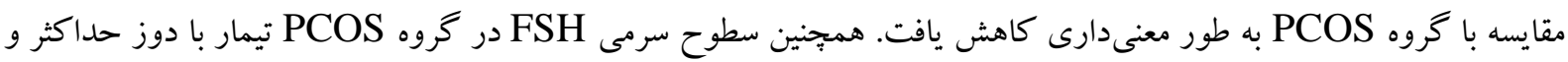

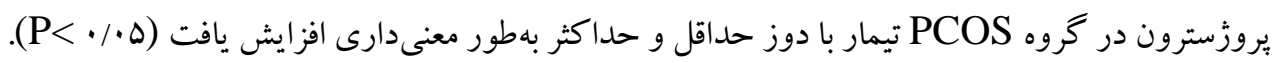
نتيجه كيرى: اثرات مفيد تر كيب عصارهى سياهدانه و عسل مشاهده شد؛ اما مطالعات بيشترى مورد نياز است.

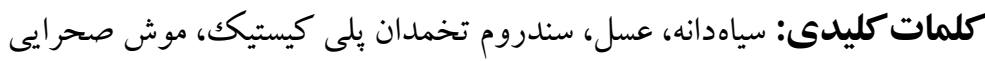

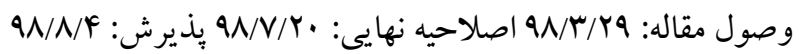


مقاومـت بـه انسـولين حاصل از افزايش ه-TNF يكى از علـل ايجـاد كيستهاى تخمدانى است(ب). روشهاى درمانى متعددى براى كنترل و يا درمان علامتى إنى

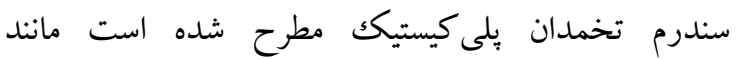
تغييرعادت زندگى، جراحى و مصرف دارو كه در حال

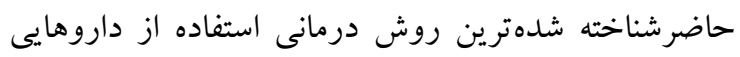
مانندكلوميفن سيترات، متفورمين، لتروزول و تامو كسيفن

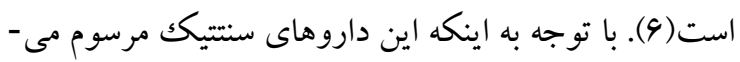
تو انند باعث عوارض جانبى ناخواسته شوند شناسايى و تهيه داروهاى جايخزين داراى اهميت زيادى است؛ لذا امروز هم تهن

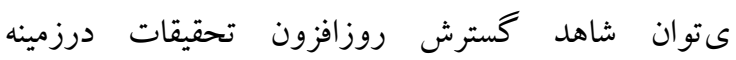
مكملهاى طبيعى، تجويز و كاربرد آنها دركشورهاى تهاى مختلف جهان بود. كياه سياهدانه با نام علمى (Nigella sativa) از خانو آنادهى آلاله (Ranunculaceae) است؛ بهطورمعمول بهعنوان دانه سياه در طب سنتى شناخته شده است؛ كه در بسيارى از نقاط دنيا روييده يا كشت مىشود. دانه هاى گياه منبع اجزاى دئي اصلى آن هستند. سياهدانه بيش از دو هزار سال است كه به-

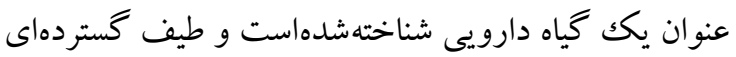
ازخواص يزشكى شامل اثرات ضد ميكروب، ضد تومور، ضدويروس، ضد درد و التهاب وآنتى - اكسيدانيرا دارا است. دانههاى سياهدانه داراى جربى، فيبر، املاح (يونها) و و عناصرى از قبيل روى، مس، سديم، آهن، كلسيم و ويتامين هاى مختلفى از جمله آسكورييك، تيامين، نياسين و اسيد

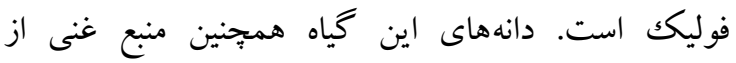
استرهاى اسيد جرب مثل اسيدلوريك، اسيدميريستيك،

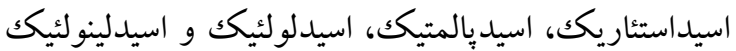
است(V). حضرت محمد (ص) فرمودند كه سياه دانه درمان

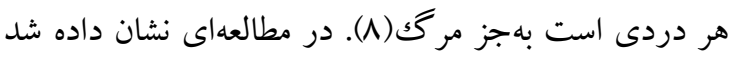
كه تيمار تخمدان با روغن سياددانه به طور معنىدارى از

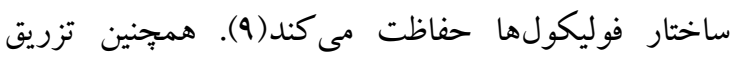

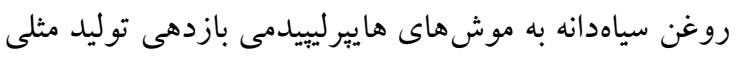

مقدمه

سندروم تخمدان يلى كيستيك (PCOS) يك اختلال ناهمگن بيجِيدهى زَنتيكى، اندو كرينى و متابوليكى است كه تقريباً ه تا •ا درصد زنان در سن بارورى را مبتلا مى كند. اف با عدم تخمكك كذارى مزمن، تخمدان كيستيك،

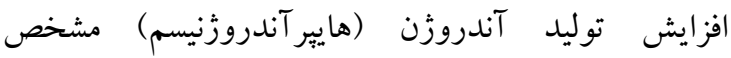

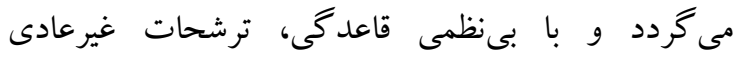

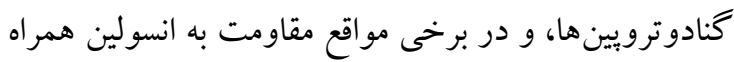

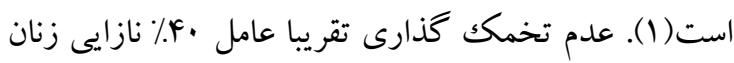
است و بسيارى از اين زنان مبتلا به PCOS هستند(Y). علت هنوز نامعلوم است و ممكن است بر اثر عوامل PCOS

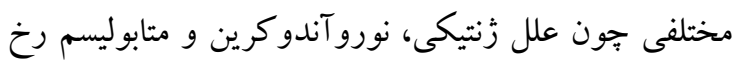
دهد. برخى محققان معتقدند كه PCOS بيمارى تخمدان

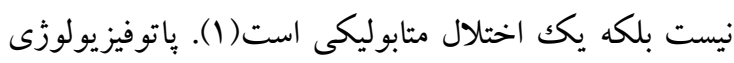

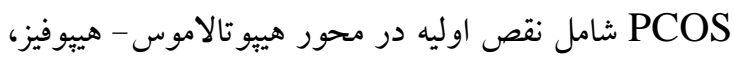
ترشح و كاركرد انسولين و عملكرد تخمدان ها است(r). وجود هيرسوتيسم، آكنه، آلويسى در مبتلايان به PCOS بهطور مستقيم با سطح آندروزن در ارتباط است و با افزايش خطر ابتلا به ديابت نوع II و سندروم متابوليك همر اه است. افزايش بيش از حد سطوح LH و انسولين عدم تعادل استروئيدوزنز را تقويت مى كند و موجب افزايش سطح آندروزن در سلولهاى غلاف فوليكولى و در نتيجه تقويت

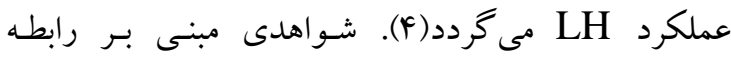

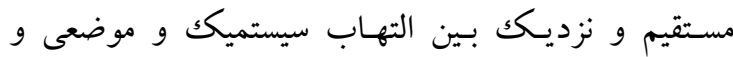
PCOS وجود دارد(ץ). گزارش شده است كه در بافت تخمدان مبتلا به سندرم تخمدان يلى كيستيك ير اكسيداسيون

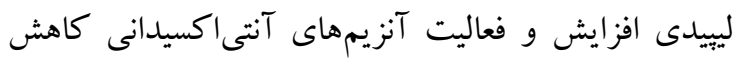
مىيابد(ه). مقاومت به انسولين ايجاد شده در PCOS و

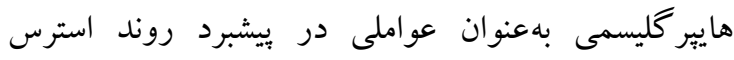

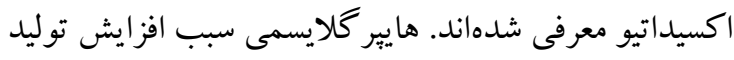

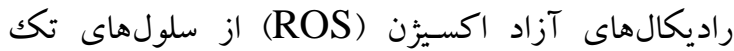
هستهاى خون اين بيماران مى گردد. ROS سبب القاى

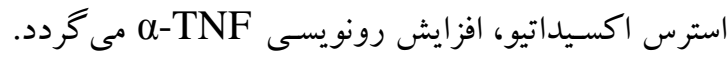

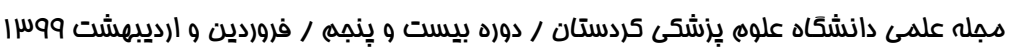


اينكه تاكنون گزارشى مبنى بر اثر مخلوط عصاره سياهدانه و عسل بر عوارض مبتلايان به تخمدان بلى كيستيك ارائه نشدهاست، هدف از بيزوهش حاضر تعيين اثر عصاره

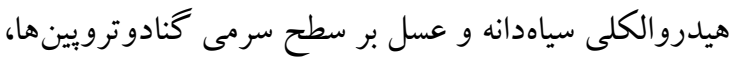
استروزن، يروزسترون و تستوسترون در موش صحرايى مدل سندرم تخمدان يلى كيستيك است.

\section{مواد و روشها} حيوانات

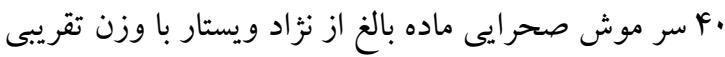
 اسلامى كازرون تهيه و در همان مركز در قفسهاى براى مخصوص با فضاى استاندارد وتحت شر ايط محيطى مناسب

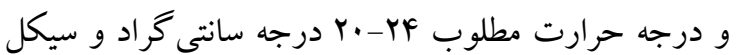
روشنايى و تاريكى باساعته و دسترسى آزادانه به غذا و آب، به مدت دو هفته نخههارى شدند. عسل طبيعى از روستاى بزكويه (شهرستان املش استان كيلان) خريدارى شد. عصارهى هيدروالكى سياهدانه توسط إن روني

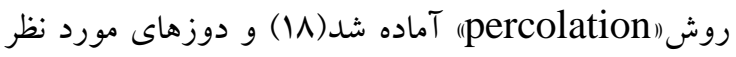
تهيه گرديد و با دوز دوزهاى مورد نطر محلول عسل مخلوط (r.) Y... mg/kg و إن...mg/kg

سيكل استروس توسط اسمير وازن مورد بررسى قرار گرفت.

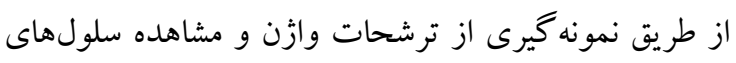

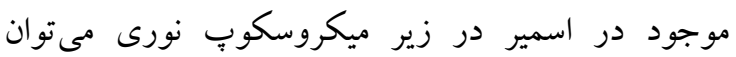
حيوانات را از لحاظ نظم مر احل سيكل جنسى بررسى كرد. براى اين منظور،بهوسيله بييت پاستوراستريل شده مقدارى سرم فيزيولوزى بههمراه سلولهاى شستشو شده از ديواره

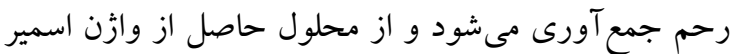

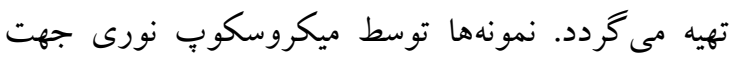

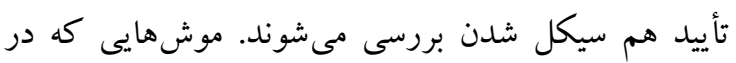

آنها را بهبود بخشيد( • (1). در مطالعات مختلف اثرات آنتىاكسيدان سياهدانه و جزء اصلى آن كه تيمو كينون(TQ) است؛ به اثبات رسيده است(V). همجِنين سياهدانه مى تواند از راه كاهش فعاليت آنزيم استيل كو آكربكسيلاز سبب كاهش توليد اسيد جرب كبدى و به دنبال آن بهبود مقاومت به

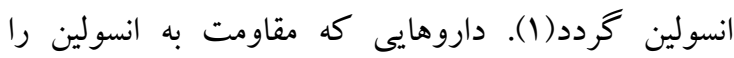
كاهش مسىدهند، غلظت آندروزنهاى خون را كاهش و تغييرات متابوليكك ايجاد شده را تا حدودى اصلاح مى مهئ

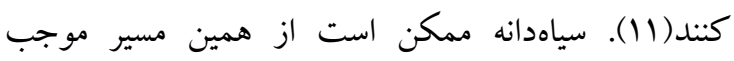
كاهش علائم PCOS Fر دد. عسل يكك محصول طبيعى زنبور عسل است؛كه از شهد كلها جمع آورى مىشود و يكى از نعمتهاى شگَفت آور

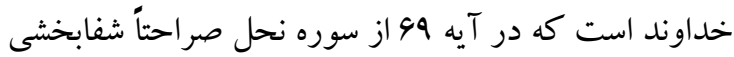

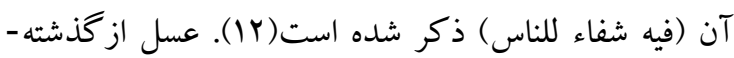
هاى خيلى دور بهعنوان يكك ماده داروئى مؤثر مورد توجه

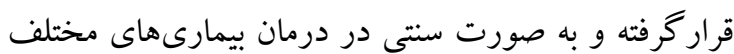
از جمله التيام زخمها، يمارىهاى شكم و سل به كار رفته است(r|). مطالعات بسيارى نشان دادهاند كه عسل محافظ خوبى در برابر استرساكسيداتيواست(f). اثر عسل بر روى بارورى هم مورد مطالعه قرار گرفته است كه نتايج بهدست آنت آمده نشان از افزايش اسبرماتوزنز در مردان و بهبود بارورى بهري

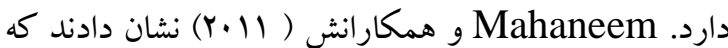

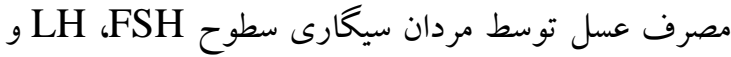

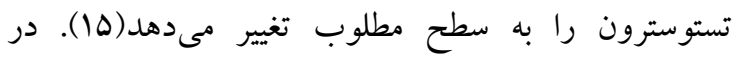

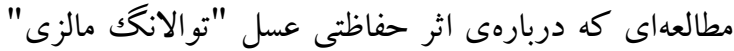

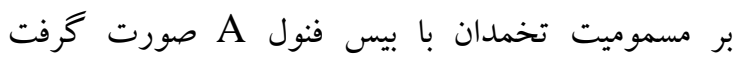
كزارش شد كه تيمار با عسل ناهنجارىهاى مرفولوزيك لهن

موجود در فوليكولهاى تخمدان را بهبود مىبخشد(19). مخلوط عسل طبيعى و سياهدانه ساليان متمادى در نقاط مختلف جهان به عنوان يكك درمانخر طبيعى مورد استفاده قرار گرفتهاست. در ايران مخلوط سياهدانه و عسل (دوسين) در طب سنتى و اسلامى استفاده مىشود(IV). با توجه به 
هاى FSH است استروزن، يروزسترون و تستوسترون به روش الايزا اندازه گيرى شد.كيتهاى مورد استفاده براى هورمونهاى FSH و روت الايز جين (Cat.No:E1037Ra و Cat.No:E0182Ra) و و و براى هورمونهاى استروزن، بروزسترون و تستوسترون

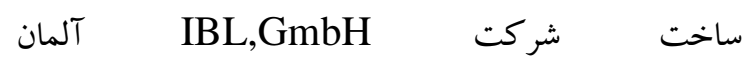
و Cat.No:RE52231 ،Cat.No:RE52041) (Cat.No:DB2181 روش تجزيه و تحليل اطلاعات نتايج بهدست آمده با استفاده از تست P< مورد ارزيابى قرار گرفت و تغييرات هUKEY معنىدار در نظر كرفته شد. تمام آناليزها بهوسيلهى نسخه

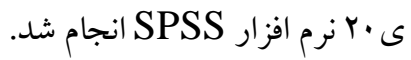

\section{يافته ها}

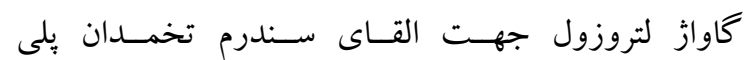
كيستيك، منجر بـه كاهش سطح سرمى FSH و ترولى

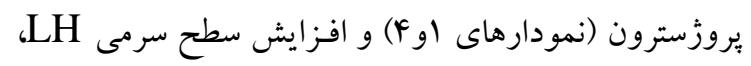

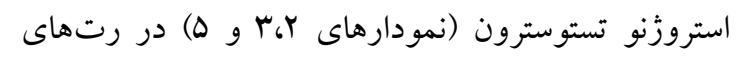
PCOS تغييرات از نظر آمارى ه/. P معنىدار بود. در اين

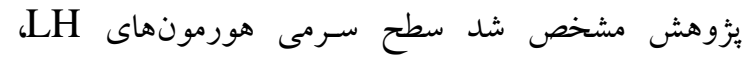

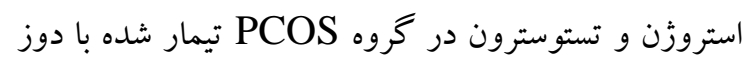
حداكثر عصاره هيدروالكلى سياهدانه و عسل (تركيب

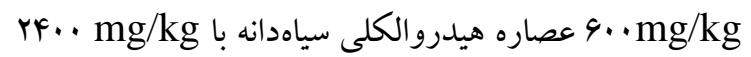
عسل) بهطور معنىدارى نسبت به گروه PCOS كـاهش هـ

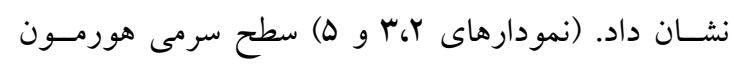
FSH در گ تـروه PCOS تيمار شده بادوز حداكثرعصاره هيدروالكلى سياهدانه و عسل (تركيب

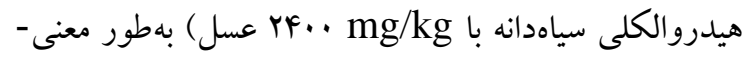

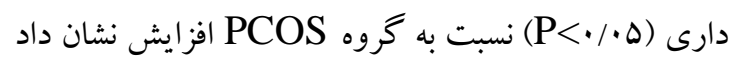

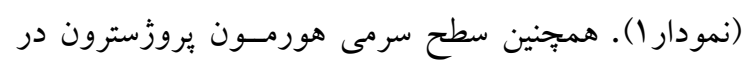

مرحلهى استروس سيكل توليد مثلى قرار داشتند انتخاب

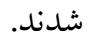
در اين تحقيق براى القاى فنوتيب سندروم تخمدان يلى -

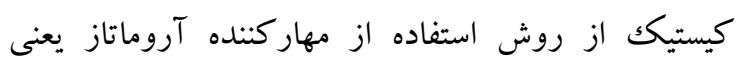

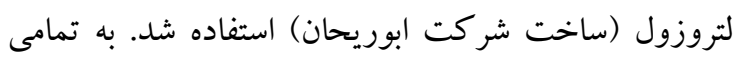
موشها در مرحله استروس سيكل توليدمثلى، مقدار اmg/kg قرص لتروزول كه در حلال كربو كسى متيل

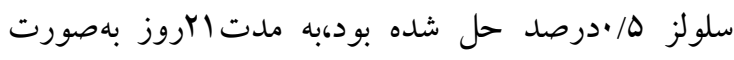

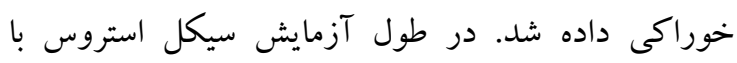

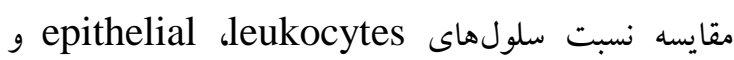

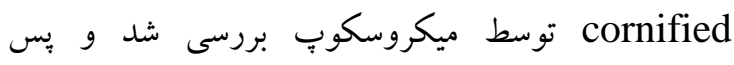

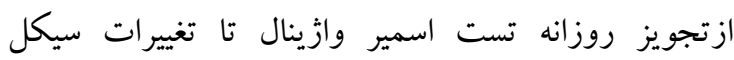
استروس و نامنظمشدن آن و رسيدن به مرحله اسمير وازينال شاخى بايدار ادامه بيداكرد(Y) (Y). موشهاى صحر ايى بهطور تصادفى به هـ گروه ^ تايى تقسيم

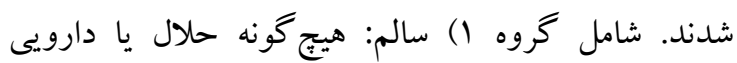

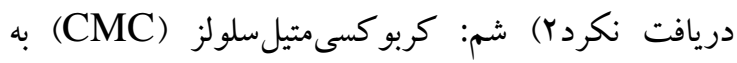
صورت كاواز (خوراكى) يه مدت الr روز دريافت كردند. r) گروه PCOS

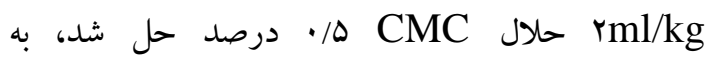

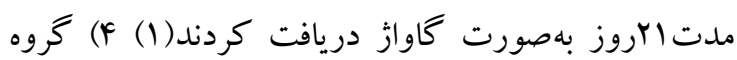

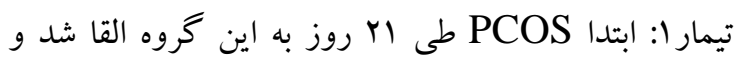

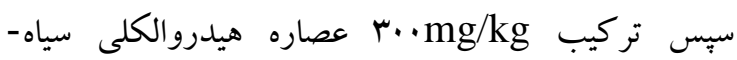

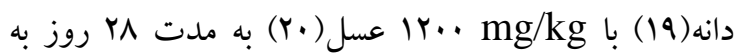

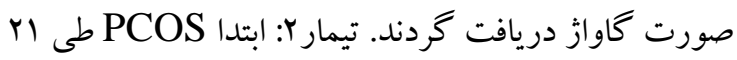
4..mg/kg روز به اين خروه القا شد و سبس تركيب

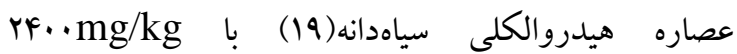

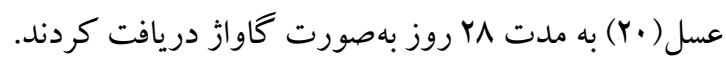

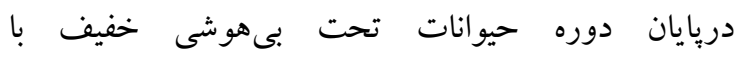

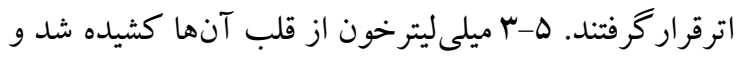

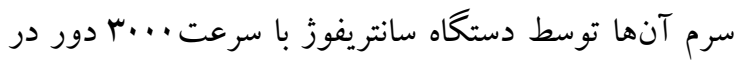
دقيقه وبه مدت لدقيقه جدا شده و غلظت سرمى هورمون- 
سياهدانه با FF.. mg/kg عسل) عصاره هيدروالكلى سياهدانه و عسل به طور معنىدارى (ه/./P< كروه PCOS افزايش نشان داد (نمودار\&).
گــــ PCOS تيمار شده با هر دو دوز حداقل (تركيب

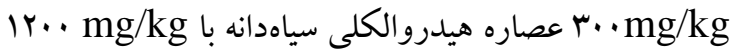
عسل) و حداكثر (تركيب

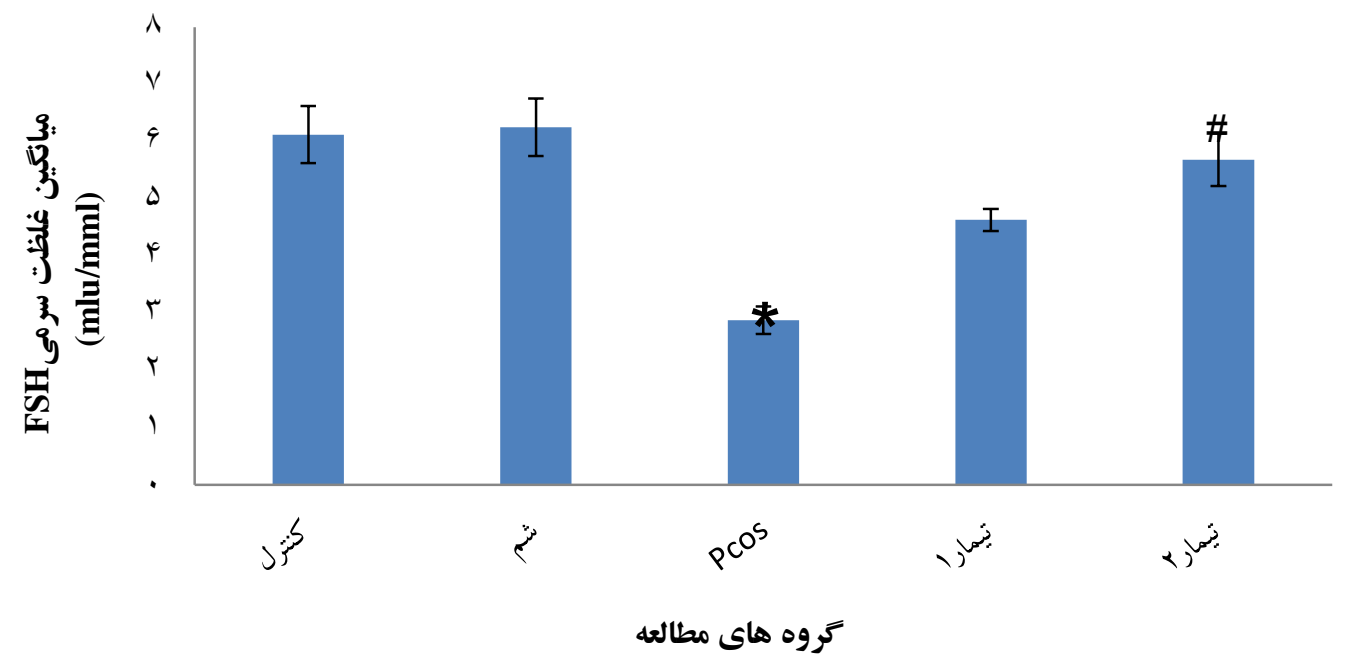

نمودار ا. مقايسه ميانكين تغييرات سرمى هورمون FSH در كروههاى مختلف آزمايشى

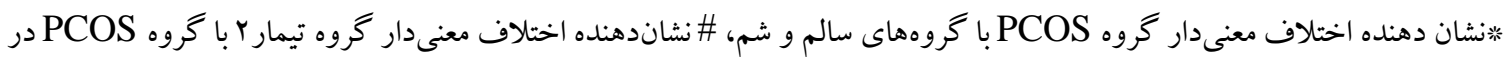

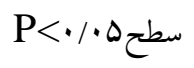

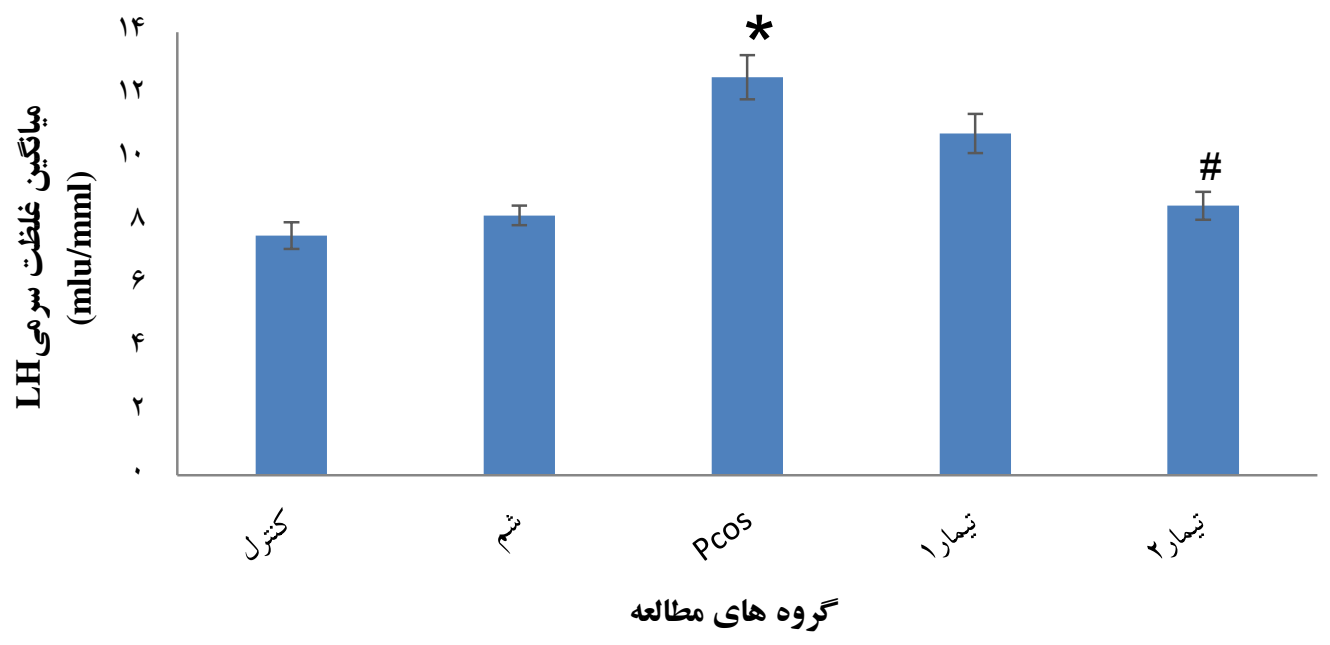

$$
\text { نمودار r. مقايسه ميانگين تغييرات سرمى هورمون LH در گرووهاى مختلف آزمايشى }
$$

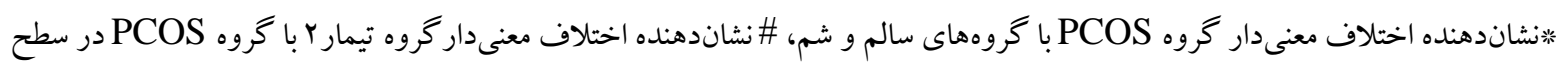
$\mathrm{P}<\cdot / \cdot \Delta$ 

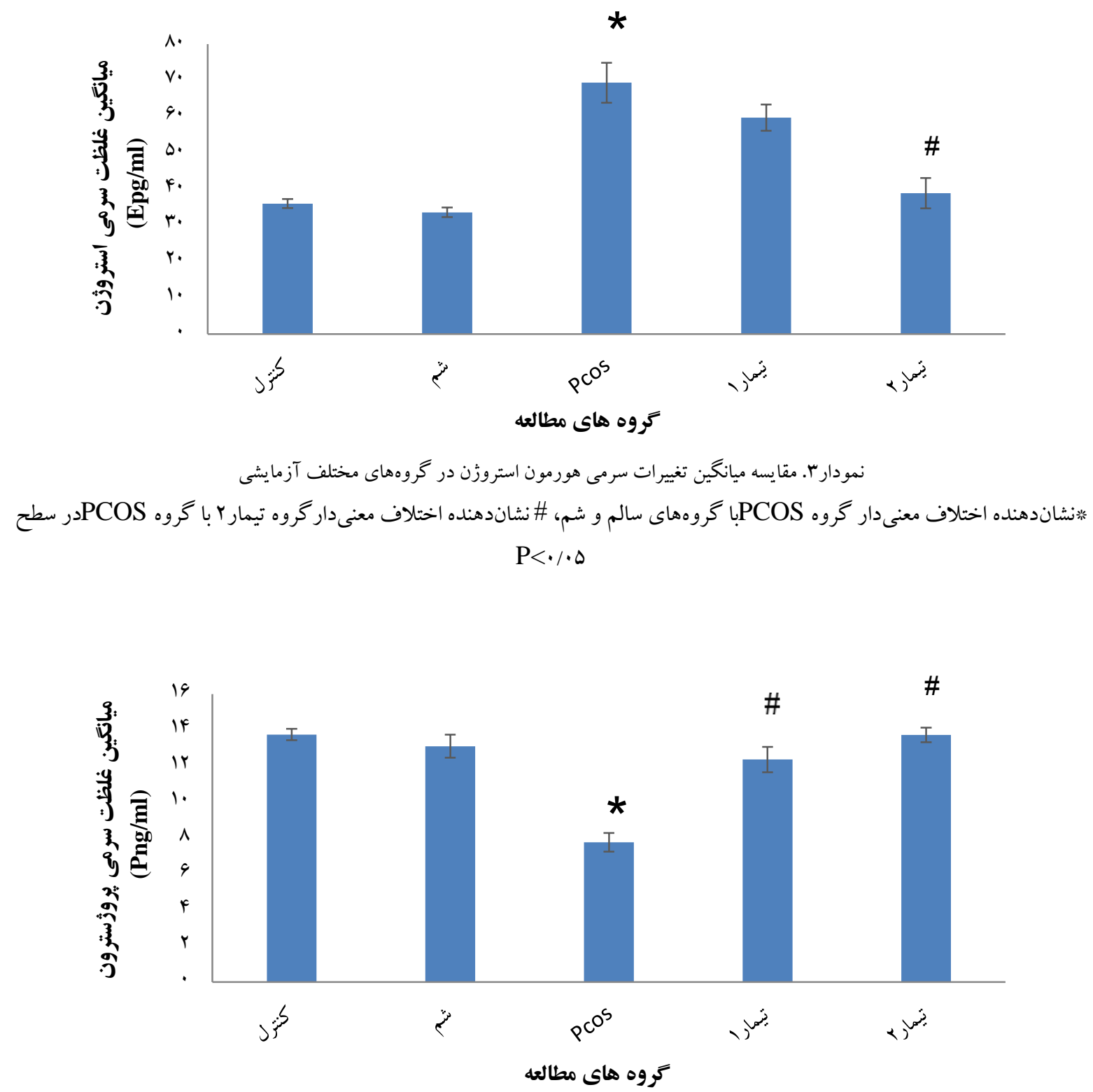

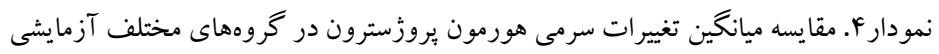

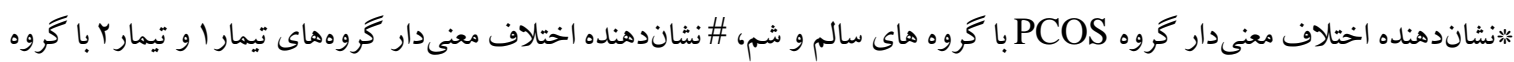
$\mathrm{P}<\cdot / \cdot \Delta$ PCOS 


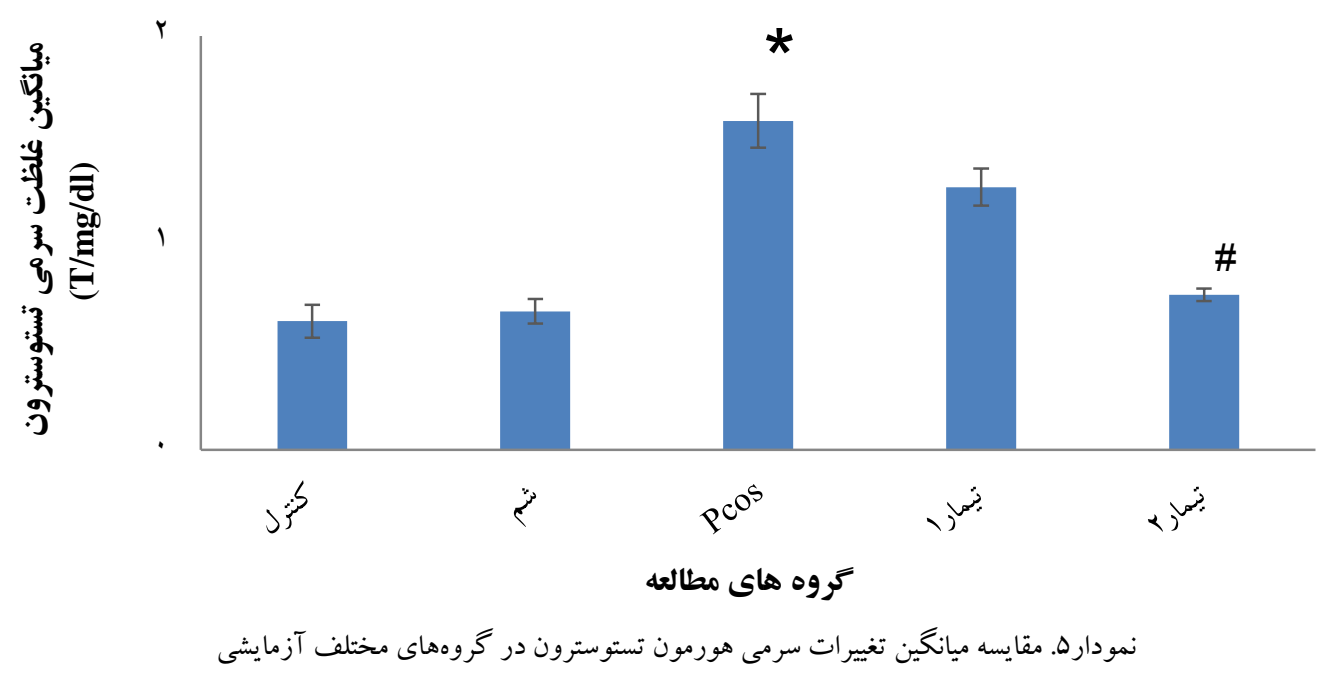

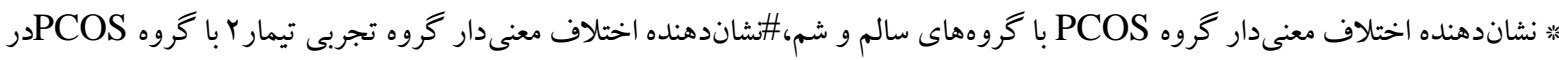

$$
\mathrm{P}<\cdot 1 \cdot 0 \text { سطح }
$$

حداكثر عصاره سياهدانه و عسل، افزايش معنى دارى را نسبت

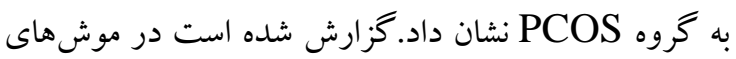
مبتلا به PCOS تغييرات سرولوزيكك بهصورت كاهش

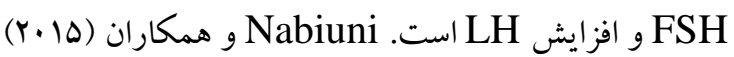
در مطالعه خود ززارش كردند كه در موشهاى صحرايى

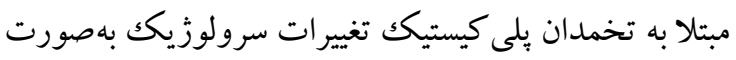

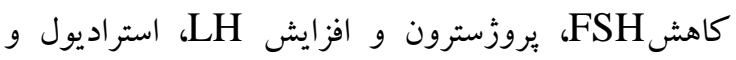

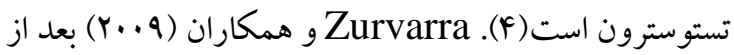
تيمار موش صحرايى توسط لتروزول جهت ايجاد مدل حيوانى PCOS بيان كردند كه سطح سرمى هورمون تستوسترون در گروه تيمار شده توسط لتروزول افزايش بيدا كرده و ميزان هورمون يروزسترون كاهش ييدا كرد(Y)). در تحقيق حاضر نتايج مشابهى از نظر تغييرات هورمونى همسو با نتايج تحقيقات فوق بهدست آمد. Doldi و همكــاران

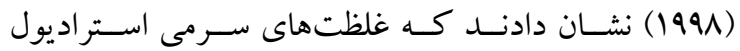
و بروزسترون بهترتيب در نمونه PCOS كاهش و افزايش معنىدارى نشان داد كه با نتايج حاصل از اين يزوهش همسو نيست(بr). استرس اكسيداتيو، عدم تعادل بين توليد

\section{بحث}

براى القاء فنوتيب سندرم تخمدان بلى كيستيك، روشهاى

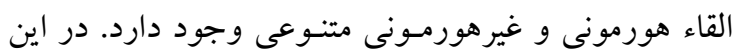

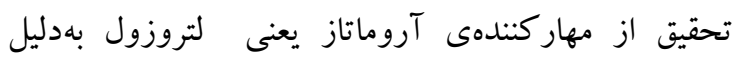
تو انايى بيشتر در مهاركردن آنزيم آروماتاز نسبت به مهار

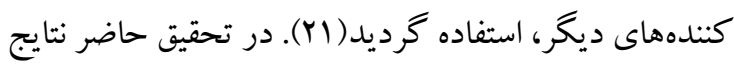
حاصل نشان داد كه استفاده از لتروزول جهت القاء سندروم

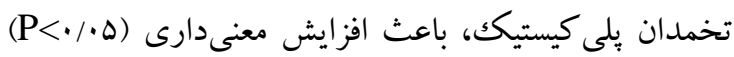
در ميانخين هورمونهاى LH، استروزن و تستوسترون و نيز كاهش FSH و يروزسترون در سرم خون رتهاى مبت مبتلا به

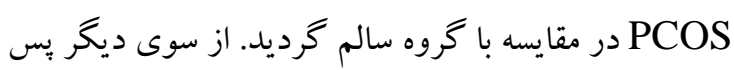
از دريافت تركيب عصاره هيدروالكلى سياهدانه و عسل ميزان هورمونهاى LH، استروزن و تستوسترون در رت درون هاى PCOS تيمار شده با دوز حداكثر عصاره سياهدانه و هورئ

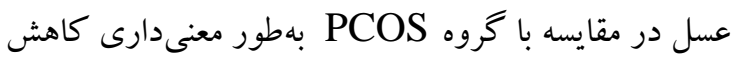

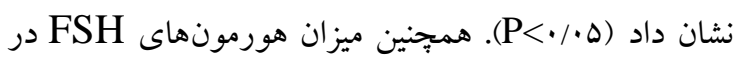

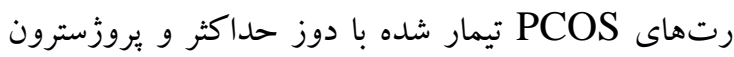
در رتهاى PCOS تيمار شده با هر دو دوز حداقل و 
مى كند. بـا توجسه بـه نقـش جشماكير آنـزيم

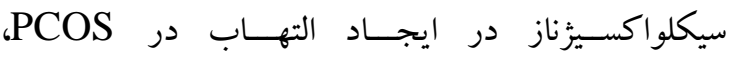

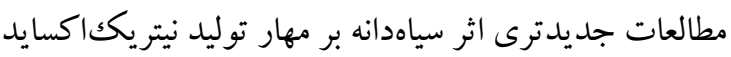

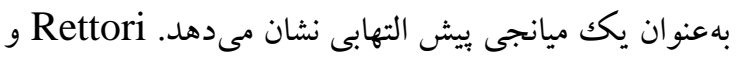

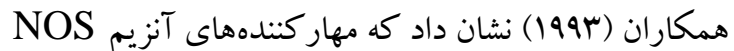
منجر به كاهش بالسهاى ترشحى LH در شرايط برون تنى مى گردند، ولى بر پالسهاى ترشحى

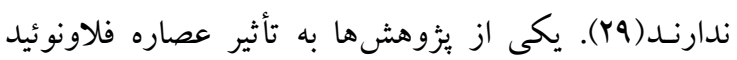

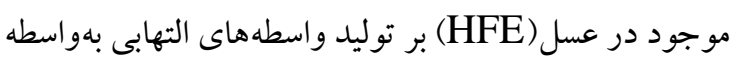
ميكرو كلياى N13 تحريك شده با لييو يلى ساكاريد اشاره

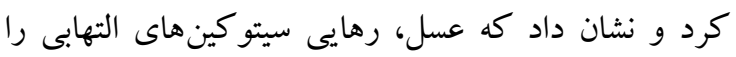

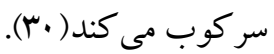
در يزوهشى اثر لينوليكك اسيد مزدوج (از تركيبات سياهدانه)

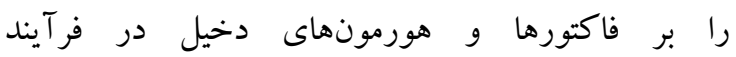
تخمكك كذارى در موش آزمايشگاهى مورد بررسى قرار

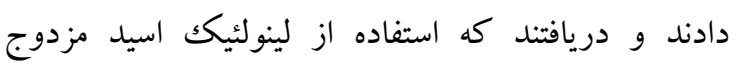
مى تواند باعث كاهش ترشح FSH و به دنبال آن كاهش

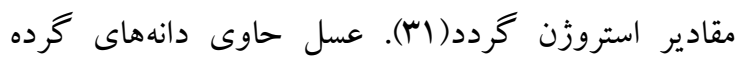
است. در مطالعهاى فعاليت آنتىاستروزنى گرده كياه C.incanul ارزيابى شد كه اين فعاليت باعث كاهش خطر ابتلا به سرطان مىشود؛ بنابراين درمان با عسل كه حاوى

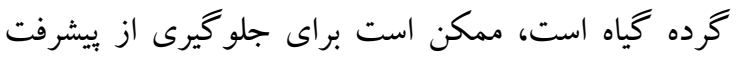
انواع بيمارىهايى كه بهواسطهى استروزن ايجاد مى گرددد،

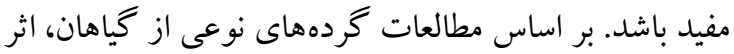

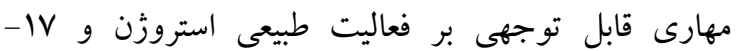
بتاستراديول دارند(r) و فعاليت استروزنى و آسيبهاى كروموزومى را سركوب مى كنند. مىتوان كفت كاهش

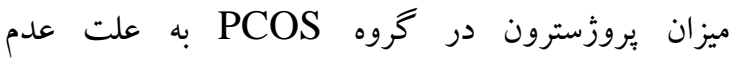
تخمكك گذارى و كاهش جسم زرد است(بس). نتايج يُزوهشى نشان داده كه دانهى گرده باعث افزايش ميزان

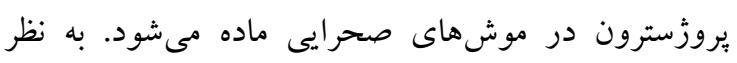

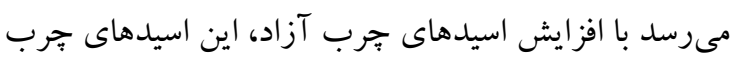

راديكالهاى آزاد و ظرفيت دفاع آنتىاكسيدانى بدن است

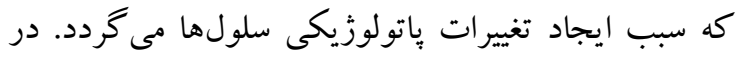
PCOS

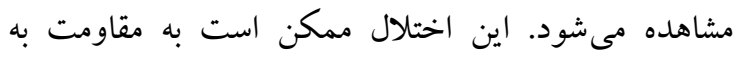

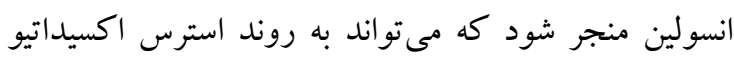
نسبت دادهود(سا, 1). PCOS با تغيير در هورمونهاى جنسى بهخصوص استروئيدها در ارتباط است. در PCOS

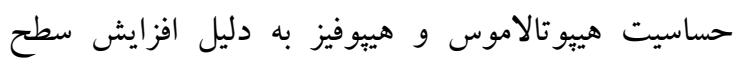
استروزن افزايش يافتهاست. تغيير روند توليد استروئيد جنسى، اختلال سيستم متابوليكك و جاقى از جمله مواردى لئى

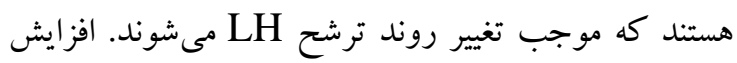

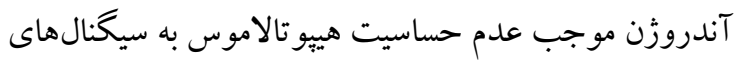
بازخورد منفى بروزسترون/ استروزن مىشود كه اين نيز

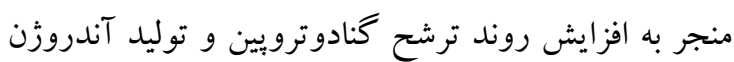

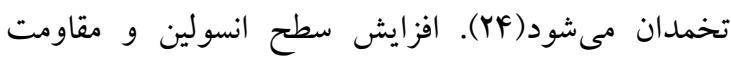
انسولين، مستقيم يا غيرمستقيم (بهواسطه تشديد روند توليد

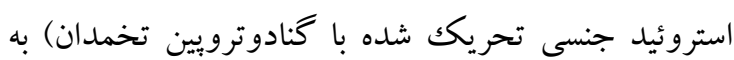

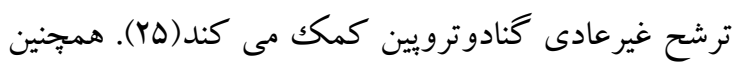

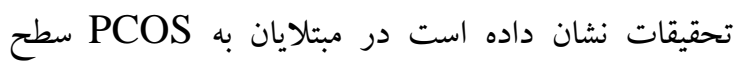

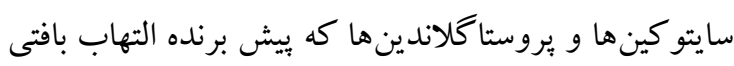

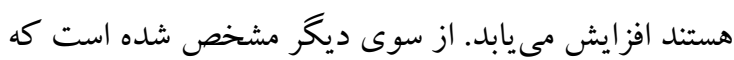

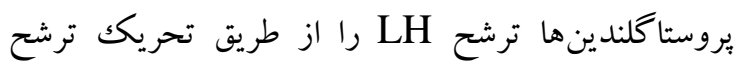
هورمون آزاد كننده كنادوترويين و مهار فيدبك منفى ترنى هورمونهاى تخمدانى افزايش مىدهد(Y) (Y). در يكك مطالعه

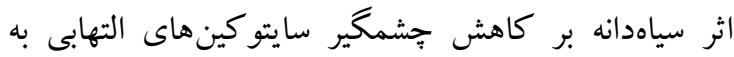
اثبات رسيد(YV).در مطالعهى ديخرى گاواز تيمو كينون

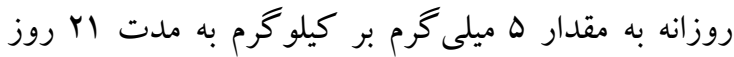
سبب كاهش سطح سايتو كينهاى التهابى و افزايش سطح

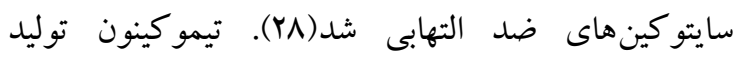
ايكوزانوئيد و براكسيداسيون ليييد غشايى را از طريق مهار

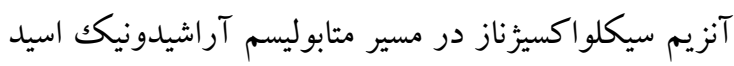
مهار مى كند؛ بنابراين از اين طريق نقش ضد التهابى رائ را ايفا 
غالب LH بر FSH كاسته مىشود. كه خود مى تواند دليلى بر راه اندازى مجدد مسير طبيعى هورمونهاى جرخه جنسى

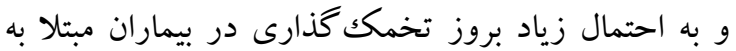
ff باشد. فيتواسترولها، باعث كاهش بf PCOS

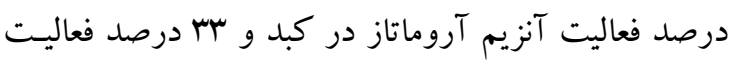

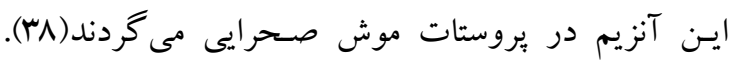
همجنين تحقيقات انجام شده روى رزيم غذايى غنى از

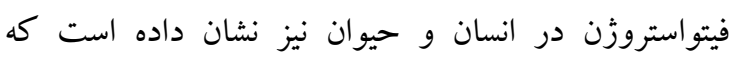

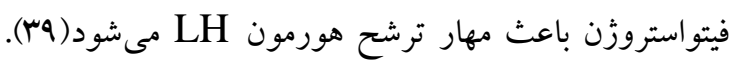
Tsiapara

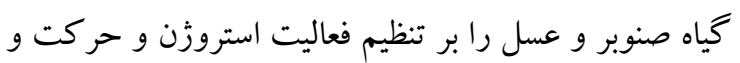
يويايى سلولهاى سرطان سينه (MCF-7) مورد آزمايش قرار دادند و به اين نتيجه دست يافتند كه عسل بسته به

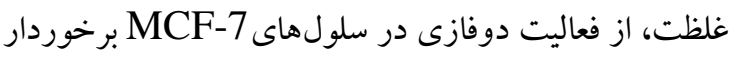
است كه در غلظت هاى كم، اثر ضد استروزنى و در غلظتهاى بالا، اثر استروزنى را بروز مىدهد(·F). محدوديت اصلى اين مطالعه تعداد اندكى يُزوهشها دربارهى اثات دوسين بود. ما در اين مطالعه كوشش كرديم تا مكانيسم احتمالى اثرات آن را بر PCOS با توجه به به دان تأثيرات سياهدانه و عسل بررسى كنيم. همجينين عدم بررسى

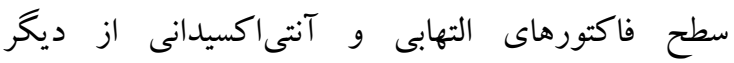
محدوديتهاى اين مطالعه بهشمار مىرود. بيشنهاد مى شود مطالعات تكميلى در مورد شناخت دقيق مكانيسماى آنتى - مانى اكسيدانى، ضد التهابى و ضد ديابتى دوسين در كنترل اختلالات هورمونى و بافتى ناشى از سندروم تخمدان بلى إنى

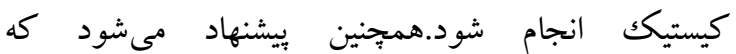
درتحقيقات آينده اثرات ماده مؤثره سياهدانه PCOS به همراه عسل در درمان (Thymoquinone) مورد بررسى قرار گيرد.
با بروزسترون در اتصال به آلبومين رقابت مى كنند، و اتصال بيشتر آنها به آلبومين، باعث افزايش يُروزسترون غير متصل برل

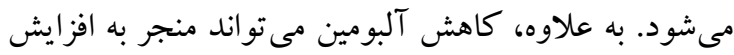
يروزسترون غير متصل شود و در نتيجه مقدار بروزسترون بلاسما زياد مىشود(YF). سياهدانه حاوى مقاديرى از

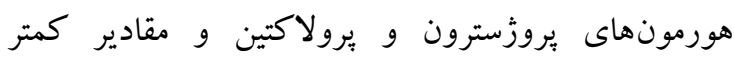
استراديول است. همجنين مطالعهاى كه بر روى عصاره هيدروالكلى سياهدانه بر موشهاى سورى ماده انجام شده، نشان داد كه تزريق عصاره هيدروالكلى اين دانه مى تواند باعث افزايش معنىدارى در سطح بروزسترون سرم خون موشهاى سورى ماده شود(هاr). در تحقيقى عدم وجود خاصيت استروزنى سياهدانه را به وسيله خاصيت ضد

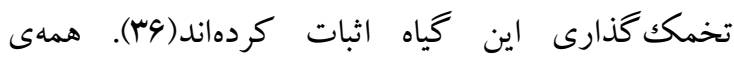
هورمونهاى استروئيدى از جمله استراديول از كلسترول مشتق مىشوند. در مطالعهاى نشان داده شد كه مخلوط سياهدانه با عسل در كاهش سطح :بروفايلهاى ليبيد مؤثر است(1). در نتيجه با كاهش غلظت كلسترول سـنتز هورمونهاى استروئيدى از جمله استراديول نيز كاهش ييسدا مى كند. اين نتايج همسو با نتايج تحقيق ما در مورد كاهش ميزان استروزن گرروه PCOS تيمار شده با دوز حداكثر و افزايش ميزان يروزسترون گروه PCOS تيمار شده با دوز حداقل و حداكثر تركيب عصارهى سياهدانه و عسل است. فيتواسترون ها از مواد طبيعى گياهى و تركيباتى مشابه كلسترول هستند كه خو اص استروزنى دارند مىتواند در جذب كلسترول اختلال ايجاد كنند و ميزان كلسترول بد خون و ترى كليسريدها را كاهش دهند و همجنين در كاهش سنتز هورمونهاى آندروزن و به ويزه تستوسترون نقش داشته باشند(rV). سياهدانه حاوى فيتو استروزن است. استفاده دراز مدت از عصارههاى گياهى كه داراى فيتواستروزنها هستند مى تواند با فيدبك منفى بر LH ميزان

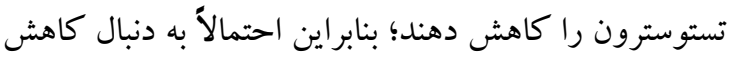

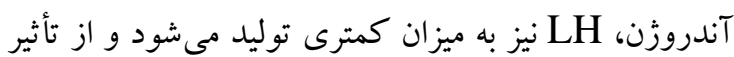


اين ئزوهش با مساعدت معاونت يزوهشى دانشكاه آزاد

اسلامى واحد كازرون انجام شد كه بدينوسيله از ايشان

تشكر و سباسگز ارى مى گردد.

با توجه به نقش عصارهى سياهدانه و عسل در تعديل غلظت

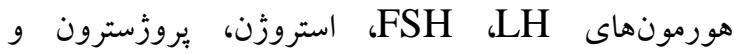

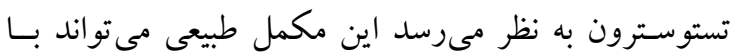

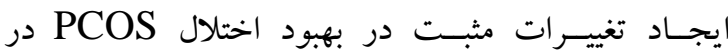

مبتلايـان مؤثر باشد.

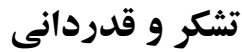

منابع

1.Naseran SN, Mokhtari M, Abedinzade M, Shariati M. The Effects of Nigella sativa Hydroalcoholic Extract and Honey on Lipid Profile and Indices of Insulin Resistance in Polycystic Ovarian Syndrome Wistar Rat Model. J Res Med Dent Sci. 2018;6(4):81-7.

2.Fleming R, Hopkinson ZE, Wallace AM, Greer IA, Sattar N. Ovarian function and metabolic factors in women with oligomenorrhea treated with metformin in a randomized double blind placebo-controlled trial. J Clin Endocrinol Metab. 2002;87(2):569-74.

3.Nabiuni M, Kayedpoor P, Mohammadi S, Karimzadeh L. Effect of silymarin on estradiol valerate-induced polycystic ovary syndrome. IAUTMU. 2015;25(1):16-26.

4.Nabiuni M, Mohammadi S, Kayedpoor P, Karimzadeh L. The effect of curcumin on the estradiol valerate-induced polycystic ovary in rats. FEYZ. 2015;18(6).

5.Fenkci V, Fenkci S, Yilmazer M, Serteser M. Decreased total antioxidant status and increased oxidative stress in women with polycystic ovary syndrome may contribute to the risk of cardiovascular disease. Fertil Steril. 2003;80(1):123-7.

6.Verit FF, Erel O. Oxidative stress in nonobese women with polycystic ovary syndrome: correlations with endocrine and screening parameters. Gynecol Obstet Invest. 2008;65(4):233-9.

7.Ziaei T, Moharreri N, Hosseinzadeh H. Review of pharmacological and toxicological effects of Nigella sativa and its active constituents.I.MED.Plants. 2012.42(2):16-42.

8.Buriro MA, Tayyab M. Effect of Nigella sativa on lipid profile in albino rats. GJMS. $2007 ; 5(1)$.

9.Kamarzaman S, Shaban M, Abdul Rahman S. The prophylactic effect of Nigella Sativa against cyclophosphamide in the ovarian follicles of matured adult mice: A preliminary study. J Anim Plant Sci. 2014;24:81-8.

10.Bashandy AS. Effect of fixed oil of Nigella sativa on male fertility in normal and hyperlipidemic rats. Int J Pharmacol. 2007;3(1):27-33.

11.Dunaif A, Scott D, Finegood D, Quintana B, Whitcomb R. The insulin-sensitizing agent troglitazone improves metabolic and reproductive abnormalities in the polycystic ovary syndrome. J Clin Endocrinol Metab. 1996;81(9):3299-306.

12.Ediriweera E, Premarathna N. Medicinal and cosmetic uses of Bee's Honey-A review. Ayu. 2012;33(2):178.

13.Eteraf-Oskouei T, Najafi M. Traditional and modern uses of natural honey in human diseases: a review. Iran J Basic Med Sci. 2013;16(6):731.

14.Gheldof N, Wang X-H, Engeseth NJ. Buckwheat honey increases serum antioxidant capacity in humans. J Agric Food Chem. 2003;51(5):1500-5. 
15.Mahaneem M, Sulaiman SA, Jaafar H, Sirajudeen KNS, Ismail ZIM, Islam MN. Effect of honey on testicular functions in rats exposed to cigarette smoke. JAAS. 2011;3(1):12-7.

16.Zaid SSM, Othman S, Kassim NM. Potential protective effect of Tualang honey on BPAinduced ovarian toxicity in prepubertal rat. BMC Complement Altern Med. 2014;14(1):509.

17.Hashem-Dabaghian F, Agah S, Taghavi-Shirazi M, Ghobadi A. Combination of Nigella sativa and honey in eradication of gastric Helicobacter pylori infection. Iran Red Crescent Med J. 2016;18(11).

18.Rathi B, Bodhankar S, Baheti A. Evaluation of aqueous leaves extract of Moringa oleifera Linn for wound healing in albino rats. Indian J Exp Biol. 2006. 44(11):898-901

19.Parhizkar S, Latiff L, Rahman SA, Dollah MA, Hanachi P. Assessing estrogenic activity of Nigella sativa in ovariectomized rats using vaginal cornification assay. Afr J Pharm Pharmacol. 2011;5(2):137-42.

20.Mohamed M, Sulaiman S, Jaafar H, Sirajudeen K. Effect of different doses of Malaysian honey on reproductive parameters in adult male rats. Andrologia. 2012;44:182-6.

21.Demirel MA, Ilhan M, Suntar I, Keles H, Akkol EK. Activity of Corylus avellana seed oil in letrozole-induced polycystic ovary syndrome model in rats. Rev Bras Farmacogn. 2016;26(1):83-8.

22.Zurvarra FM, Salvetti NR, Mason JI, Velazquez MM, Alfaro NS, Ortega HH. Disruption in the expression and immunolocalisation of steroid receptors and steroidogenic enzymes in letrozole-induced polycystic ovaries in rat. Reprod Fertil Dev. 2009;21(7):827-39.

23.Doldi N, Gessi A, Destefani A, Calzi F, Ferrari A. Polycystic ovary syndrome: anomalies in progesterone production. Hum Reprod. 1998;13(2):290-3.

24.Daniels TL, Berga SL. Resistance of gonadotropin releasing hormone drive to sex steroidinduced suppression in hyperandrogenic anovulation. $J$ Clin Endocrinol Metab. 1997;82(12):4179-83.

25.Patel K, Coffler MS, Dahan MH, Malcom PJ, Deutsch R, Chang RJ. Relationship of GnRH-stimulated LH release to episodic LH secretion and baseline endocrine-metabolic measures in women with polycystic ovary syndrome. Clin Endocrinol. 2004;60(1):67-74.

26.Shen S-H, Shen S-Y, Liou T-H, Hsu M-I, Chang Y-cI, Cheng C-Y, et al. Obesity and inflammatory biomarkers in women with polycystic ovary syndrome. Eur J Obstet Gynecol Reprod Biol. 2015;192:66-71.

27.Abel-Salam BK. Immunomodulatory effects of black seeds and garlic on alloxan-induced diabetes in albino rat. Allergol Immunopathol. 2012;40(6):336-40.

28.Umar S, Zargan J, Umar K, Ahmad S, Katiyar CK, Khan HA. Modulation of the oxidative stress and inflammatory cytokine response by thymoquinone in the collagen induced arthritis in Wistar rats. Chem Biol Interact. 2012;197(1):40-6.

29.Rettori V, Belova N, Dees W, Nyberg C, Gimeno M, McCann S. Role of nitric oxide in the control of luteinizing hormone-releasing hormone release in vivo and in vitro. Proc Natl Acad Sci. 1993;90(21):10130-4.

30.Erejuwa OO, Sulaiman SA, Wahab MSA. Effects of honey and its mechanisms of action on the development and progression of cancer. Molecules. 2014;19(2):2497-522.

31.Khodaei H, Chamani M, Sadeghi A, Hejazi H. Effects of Conjugated Linoleic Acid (CLA) on hormones and factors involved in murine ovulation. JRI. 2009;10(2):101-8.

32.Šarić A, Balog T, Sobočanec S, Kušić B, Šverko V, Rusak G, et al. Antioxidant effects of flavonoid from Croatian Cystus incanus $\mathrm{L}$. rich bee pollen.Food Chem Toxicol. 2009;47(3):547-54. 
33.Sadr Fozalaee S, Farokhi F, Khaneshi F. The Effect of Metformin and Aqueous Extract Foeniculumvulgare (Fennel) on EndometrialHistomorphometry and the Level of Steroid Hormones in Rats with Polycystic Ovary Syndrome. QUMSJ. 2015;8(5):12-9.

34.Moshtaghi A JH, Shariati M, Amiri J. Effects of phoenix dactylifera on serum concentration of estrogen, progesterone and gonadotropins in adult female rats. JRUMS. 2010;2(35):117-24.

35.Modaresi M, Poor-Naji N. The effect of black seed (Nigella sativa) hydro-alcoholic extract on breeding factors in female mice. JSKUMS. 2012;13.

36.Vohora S KM, Afaq S. Antifertility studies on Unani herbs. Part-II. Antiovulatory effects of Hanzal, Halun, Kalonji and Sambhala. Indian J Pharm. 1973;35:100-2.

37.Sugano M, Kamo F, Ikeda I, Morioka H. Lipid-lowering activity of phytostanols in rats. Atherosclerosis. 1976;24(1-2):301-9.

38.Awad AB, Hartati MS, Fink CS. Phytosterol feeding induces alteration in testosterone metabolism in rat tissues. J Nutr Biochem. 1998;9(12):712-7.

39.Hemayatkhah-Jahromi V, Rahmanian-Koushkaki M. Effect of hydro-alcoholic extract of Aloe vera L. on polycystic ovary syndrome in rat. FEYZ. 2016;20.

40.Tsiapara AV, Jaakkola M, Chinou I, Graikou K, Tolonen T, Virtanen V, et al. Bioactivity of Greek honey extracts on breast cancer (MCF-7), prostate cancer (PC-3) and endometrial cancer (Ishikawa) cells: Profile analysis of extracts.Food Chem. 2009;116(3):702-8. 